\title{
CEFR Based Learning Approach: Using Literature to Enhance EFL Students' Reading Skills and Critical Thinking Skills
}

\author{
Sukanya Kaowiwattanakul ${ }^{1}$ \\ ${ }^{1}$ School of Liberal Arts, University of Phayao, Thailand \\ Correspondence: Sukanya Kaowiwattanakul, School of Liberal Arts, University of Phayao, Phayao, Thailand.
}

Received: September 17, 2021

Accepted: October 15, 2021

Online Published: October 20, 2021

doi: $10.5539 /$ elt.v14n11p66

URL: https://doi.org/10.5539/elt.v14n11p66

\begin{abstract}
The purposes of this research were to: 1) study whether the use of literature activities improved EFL students' reading skills and critical thinking skills according to CEFR at $\mathrm{C} 1$ level; 2) investigate students' critical thinking skills in studying a literature course; and 3) examine students' attitudes towards the use of literature activities in developing reading skills and critical thinking skills. The sample consisted of 47 second-year English major students who were enrolled in the Introduction to Literature Course in the academic year 2020 at a public university in the northern part of Thailand. The instruments included five lesson plans using literature activities to develop reading skills and critical thinking skills, a reading test, a reflective writing task, and a list of semi-structured interview questions. T-test, mean, and standard deviation calculations including content analysis were used for data analysis. This study found that the EFL students' reading skills and critical thinking skills improved significantly following participation in literature activities based on Reader-Response theory. The EFL students demonstrated average level critical thinking skills and they held positive attitudes towards the use of literature activities for developing reading skills and critical thinking skills.
\end{abstract}

Keywords: CEFR, critical thinking skills, literature activities, reading skills

\section{Introduction}

Literature is widely recognised in EFL classrooms as a valuable source of authentic material for language improvement. It provides a good example of vocabulary use and sentence structure which are both very useful for language learning. The students also become more familiar with the language used in different real-life situations (Collie \& Slater, 2001; Hosseini \& Safari, 2018; Rew \& Moon, 2013; Yilmaz, 2012). In addition to language skill development, studying literature encourages the students to express their ideas and emotions towards the stories they read, particularly when they have to discuss or respond to the important issues embedded in the literary texts (Carrison \& Slavit, 2005; Fisher, 2003). Significantly, students can develop their critical thinking skills through written and oral discussions about the texts they read (Fisher, 2003; Kaowiwattanakul, 2009). Critical thinking skills are considered as one of the most essential learning skills for $21^{\text {st }}$ century learners as they live in ever-changing societies with increasing access to news and information from every corner of the world. It is necessary for these students to be able to differentiate, analyse, and evaluate the reliability of the received data to avoid manipulation by others.

Amidst the current trend of English language teaching to centre on use of the Common European Framework of Reference for Languages (CEFR) in curriculum design, testing and assessment, literature plays a key role in enhancing students' English language competence (Jones \& Carter, 2012). In relation to CEFR learning outcomes for reading skills, literature is described in the illustrative descriptors as necessary for students to achieve the proficiency levels. It is expected that teachers at all levels will utilise literary reading as a useful language learning resource to achieve the CEFR goal.

\subsection{Statement of the Problem}

Realising that literature offers opportunities to develop students' English language skills and critical thinking skills, integrating literary readings into EFL classrooms for the purpose of developing students' reading abilities according to CEFR levels appears rare in the literature. Many communicative classrooms tend to rely on overall reading comprehension rather than imaginative writing texts (Jones \& Carter, 2012). Indeed, most studies have focused on the use of CEFR to assess students' language proficiency and for surveying teachers' and students' 
opinions towards the implementation of CEFR in the classroom (Jiménez-Muñoz, 2014; Kanchai, 2019; Phaisannan, Charttrakul, \& Damnet, 2019; Waluyo, 2019; Zou \& Zhang, 2017). As such, there has not been a lot of attention in the EFL teaching context given to the relationship between literary reading and CEFR in relation to critical thinking skills.

\subsection{Objectives of the Study}

Given the limited number of studies of students' reading literature competence according to CEFR levels and critical thinking skills, the aim of this study was three-fold. First, to examine whether use of literature activities improved the reading skills and critical thinking skills of EFL students according to CEFR at C1 level. Second, to investigate EFL learners' critical thinking skills in studying a literature course. Third, to examine EFL learners' attitudes towards the use of literature activities in developing reading skills and critical thinking skills.

\subsection{The Common European Framework of Reference for Languages (CEFR)}

The Common European Framework of Reference for Languages (CEFR) is defined as an international guideline describing language competence of English language users at different levels (Council of Europe, 2018). At an early stage, it was utilised as a major language learning approach for learners of different languages as part of the administrative policies in education, workplace entry, immigration, and citizenship in Europe (Council of Europe, 2001; Tylor, 2004). More recently, it is widely employed as a framework for developing teaching and learning a foreign language in other non-European countries.

The main goal of the framework is to provide a standard or international benchmark for language assessment and language proficiency. The CEFR scales are divided into six levels of language proficiency: A1, A2, B1, B2, C1, and C2 (Cambridge English, 2016). With the focus on communicative competence, CEFR views language as a tool for social, educational, and career success. Therefore, its emphasis is on describing what learners can achieve at different proficiency levels by introducing the 'can do' statements. These statements identify the language ability that learners at each level should demonstrate in the area of spoken and written reception, interaction, and production (Council of Europe, 2018). Nevertheless, there are some problems and limitations arising from CEFR implementation in many countries (Fulcher, 2004). These include teachers' insufficient knowledge and experience of CEFR, teachers' language proficiency, lack of experts producing local CEFR textbooks, and lack of training to guide teachers on how to integrate CEFR in their teaching classroom. There is also the misconception that CEFR plays a role as a language proficiency measurement rather than a goal for describing language learning ability (Foley, 2019). In 2018 the modified version of CEFR was launched by the Council of Europe to deal with these issues and criticisms as well as to update the concepts related to native-speakerism, plurilingual, and pluricultural competence that may be absent in the original version published in 2001 (Council of Europe, 2018). Specifically, in this updated version, CEFR gives more focus to the varieties of English used for communication in the context of English as a lingua franca and considers the need for multiculturalism awareness to be a competent language user in a global setting.

\subsection{Literature and CEFR}

The importance of literary reading in CEFR is presented in relation to communicative competence in the aesthetic uses of language essential for both speaking and writing skills. This is achieved through various creative activities such as "singing, retelling and rewriting stories, listening to, reading, writing and speaking imaginative texts including audio-visual texts, carton, picture stories, performing scripted or unscripted plays, and the production, reception and performance of literary texts" (Council of Europe, 2001: 56). In the modified version of CEFR (2018), literature is mentioned in three new scales of illustrative descriptors: reading as a leisure activity, expressing a personal response to creative texts, and analysis and criticism of creative texts. Being a reception activity, 'reading as a leisure activity' is represented as one of the reading genres of overall reading comprehension in communicative language activities. Reading as a leisure activity includes both engaging with fiction and nonfiction texts, including creative texts, magazines, newspaper articles, blogs, and biographies. In terms of 'expressing a personal response to creative texts' including literature, the scales focus on the readers' responses to works of literature in relation to five dimensions: explaining what readers like about or was interesting about the work, describing characters, relating to the readers' experiences, relating feelings and emotions, and interpreting the texts. Lastly, regarding 'analysis and criticism of creative texts' including literature, this scale is appropriate for learners at upper secondary school and university levels as it requires higher order thinking skills. The focus is on three aspects including "comparing different works, giving a reasoned opinion of a work, and critically evaluating features of the work, including the effectiveness of techniques employed" (Council of Europe, 2018: 117). Therefore, it could be claimed that literature plays a crucial role in providing the source of aesthetic language use for learners, particularly learner at the higher level 
of education, who must demonstrate the ability to do more than provide an appreciative response to a literary text. Instead, they are required to think critically, analyse, and evaluate a literary work using supporting evidence and arguments. All in all, incorporating literature into language learning activities according to CEFR benchmarks can promote learners' cognitive and affective competence development.

\subsection{Reader-Response Theory}

As originated in the field of literary criticism, a Reader-Response theory is viewed as a new route directed away from the text-centred approach. Contrary to the New Criticism which attempts to objectively see a text without the readers' feelings and emotions, the major theme of the Reader-Response approach emphasises readers' aesthetic experiences while anticipating the text. The core concept in Reader-Response theory is based on the reading process and concentrates on three essentials: the text, the reader, and the reader's interaction with the text (Rosenblatt, 1938). Being one of the pioneers of the Reader-Response approach, Rosenblatt (1938) describes the aesthetic reading process as involving the personal life experiences the reader brings to their interaction with the texts. Each reading is unique since the reader draws on his or her personality traits, beliefs, and past memories to interpret the text. In this regard, reading becomes a dynamic process which requires readers to be active and reflective rather than passively absorbing what they read.

Iser (1978) also discusses the readers' role in the Reader-Response approach, asserting that it appears to have shifted from passive to active, and that the reader plays the most important role in this aesthetic response. He further claims that there are certain expectations created by the reader in every phase of reading. Therefore, the reader is required to fill in the meaning using his or her imagination depending on individual background factors such as age, gender, education, and nationality. Similar to filling the gap, the expectation or meaning can be realised by the reader confirming or reformulating. Jauss (1981) coined the term 'horizon of expectation' and asserts that this expectation can expand over time. In his view, a literary work is not a completely new set of information for the reader; it is merely structured and organised via different writing styles and strategies. Thus, readers' experiences from past readings can begin to form expectations about the new texts they read. These expectations include their schema knowledge about the plot, characters, or theme of the story which can change over time.

In a nutshell, the Reader-Response approach contributes to the readers' reading process by allowing them to freely express their feelings and emotions as well as react to what appears in the texts. By changing the reader's role from passive to active, readers are required to explore and interpret the texts using both their past reading and personal life experiences. Lastly, concept such as 'horizon of expectation' enables readers to show expression and undertake interpretation through assigned activities which place emphasis on the reader's interaction with the text.

\subsection{Critical Thinking Skills in Literary Study}

Critical thinking is defined differently across various fields of study; for instance, psychology, philosophy, and education. Some classic definitions of critical thinking provided by widely recognised scholars involve the use of reasoning to justify what one believes or does (Dewey, 1909; Ennis, 1987; Glaser, 1941). Nevertheless, differences in the detailed descriptions of critical thinking regarding the nature or distinctive features of each academic discipline should also be acknowledged.

Since this study is written in the context of literature teaching and learning, the definitions, and characteristics of critical thinking in literature discipline is clarified here. Critical thinking in literature study is described as the process to analyse language, style, and affect while acknowledging that one's reading is determined by his or her background and attitude. The "alterity" or "alterness" of the text including historical, gender, national or cultural dimensions and the use of imagination to acknowledge and explain the alterity is also highlighted in the analytical process. Additionally, this may include self-reflection or "a capacity to acknowledge and understand your own contribution to the process of the interpretation." In brief, critical thinking in literature study is identified as "the process of analysis, self-reflection and engagement with the alterity and imagination" (McGavin, 2005). Moreover, it can also be explained in terms of the ability to identify social and cultural concepts by extracting them from the literature as well as evaluating and applying these concepts to situations in life (Reiter, 2005). In this respect, critical thinking in literature has its own distinctive features which differ from those of the fields mentioned earlier. This is especially in relation to the use of imagination that arises from the nature or characteristics of literary texts written to create a certain kind of effect on the reader. Furthermore, an aesthetic interpretation that one gains from reading a particular text is another quality which makes critical thinking in literature study different from other disciplines (Kaplan, 2005). Table 1 exemplifies the descriptions 
of critical thinking skills related to literary study in the average level designed for the purpose of this study based on Bloom's cognitive taxonomy (1956).

Table 1. Descriptions of critical thinking skills in the average level

\begin{tabular}{|c|c|c|}
\hline Domains of critical thinking skills & Topics & Students were able to: \\
\hline Knowledge & $\begin{array}{l}\text { Describing plot, setting, and } \\
\text { character }\end{array}$ & $\begin{array}{l}\text { Describe plot, setting, and } \\
\text { character in some parts but some } \\
\text { are inaccurate }\end{array}$ \\
\hline \multirow[t]{3}{*}{ Comprehension } & $\begin{array}{l}\text { Expressing feelings and emotions } \\
\text { towards literary texts }\end{array}$ & $\begin{array}{l}\text { Express feelings and emotions } \\
\text { towards literary texts }\end{array}$ \\
\hline & $\begin{array}{l}\text { Explaining why certain parts or } \\
\text { aspects of a work interested him/ } \\
\text { her }\end{array}$ & $\begin{array}{l}\text { Explain why certain parts or } \\
\text { aspects of a work interested him/ } \\
\text { her but unable to support them } \\
\text { with examples and arguments }\end{array}$ \\
\hline & $\begin{array}{l}\text { Explaining relationship between } \\
\text { characters, significance events, } \\
\text { and conflicts }\end{array}$ & $\begin{array}{l}\text { with examples and arguments } \\
\text { Explain relationship between } \\
\text { characters, significance events, and } \\
\text { conflicts but unable to support } \\
\text { them with examples and arguments }\end{array}$ \\
\hline Application & $\begin{array}{l}\text { Making connections between } \\
\text { aspects of the texts and his/ her } \\
\text { real-life experience }\end{array}$ & $\begin{array}{l}\text { Make connections between aspects } \\
\text { of the texts and his/ her real-life } \\
\text { experience without supporting } \\
\text { detail from the story }\end{array}$ \\
\hline \multirow[t]{2}{*}{ Analysis } & $\begin{array}{l}\text { Analysing the author's purpose, } \\
\text { point of view, theme, trains of } \\
\text { thought and feeling, and writing } \\
\text { style }\end{array}$ & $\begin{array}{l}\text { Analyse the author's purpose, } \\
\text { point of view, theme, trains of } \\
\text { thought and feeling, and writing } \\
\text { style in some aspects, with some } \\
\text { supporting detail from the story }\end{array}$ \\
\hline & $\begin{array}{lrr}\begin{array}{l}\text { Comparing } \\
\text { considering } \\
\text { and scenes }\end{array} & \text { two } & \begin{array}{r}\text { works, } \\
\text { themes, }\end{array} \\
\text { characters, }\end{array}$ & $\begin{array}{l}\text { supporting detail from the story } \\
\text { Compare two works, considering } \\
\text { themes, characters, and scenes in } \\
\text { some aspects with some supporting } \\
\text { detail from the story }\end{array}$ \\
\hline \multirow[t]{3}{*}{ Evaluation } & $\begin{array}{l}\text { Evaluating the extent to which a } \\
\text { work meets the conventions of its } \\
\text { genre Evaluating the effectiveness } \\
\text { of writing techniques }\end{array}$ & $\begin{array}{l}\text { Evaluate the extent to which a } \\
\text { work meets the conventions of its } \\
\text { genre in some aspects with some } \\
\text { supporting detail from the story }\end{array}$ \\
\hline & \multirow[t]{2}{*}{$\begin{array}{l}\text { Evaluating the character's action } \\
\text { and decision }\end{array}$} & $\begin{array}{l}\text { Evaluate the effectiveness of } \\
\text { writing techniques in some aspects } \\
\text { with some supporting detail from } \\
\text { the story }\end{array}$ \\
\hline & & $\begin{array}{l}\text { Evaluate the character's action and } \\
\text { decision in some aspects without a } \\
\text { reasoned argument and sufficient } \\
\text { examples from the story }\end{array}$ \\
\hline
\end{tabular}

\section{Method}

\subsection{Participants}

Forty seven second-year English major students (10 males and 37 females) enrolled in the Introduction to Literature Course in the third semester of the academic year 2020 at a medium-sized public university in Northern Thailand were selected by purposive sampling method based on the researcher's assigned teaching course. 


\subsection{Research Design}

A quasi-experimental design was adopted for this study. A single group pre-and post-test study was conducted to compare the students' English reading abilities before and after the implementation of literature activities based on Reader-Response theory. Both quantitative and qualitative research methods were employed to obtain rich data sets for analysis.

\subsection{Research Instruments}

The instruments used in this study were five lesson plans using literature activities based on Reader-Response Theory to promote reading and critical thinking skills, a reading test, a writing rubric, a reflective journal, and semi-structured interviews questions.

First, the five lesson plans using literature activities based on Reader-Response theory were implemented by the researcher. The plans were approved by three experts who have been working in the fields of English literature and English language teaching for more than 10 years. The literary texts used in this study included two short stories, two novels, and two poems. They were Cat in the Rain by Ernest Hemingway, Little Red Riding Hood by James Finn Garner, The Little Prince by Antoine de Saint-Exupery, Frankenstein by Mary Shelly, To the Virgins to Make Much of the Time by Robert Herrick, and The Ruined Maid by Thomas Hardy, respectively. The literary works, all written in English, were confirmed by the experts to include themes promoting critical thinking skills. Moreover, they were deemed to be of suitable length and level of English language appropriate to CEFR at C1 level in terms of linguistic and syntactic aspects. They also emphasise six key concepts corresponding to 'reading as a leisure activity': 1) length, variety of texts and whether there were illustrations; 2) type of texts, from simple descriptions of people and places, through different types of narrative texts to contemporary and classical writing in different genres; 3 ) topics, from everyday concrete and abstract situations to literary themes; 4) type of language, from simple to stylistically complex; 5) ease of reading, from guessing with the help of images, through reading with a large degree of independence, to appreciating a variety of texts; and 6) depth of understanding, from understanding an outline/ the main points to understanding implicit and explicit meanings.

The design of the learning activities reflected Reader-Response theory in five ways: 1) building schema knowledge necessary for text comprehension; 2) interacting with texts; 3) creating initial response and interpretation; 4) sharing and discussing response and interpretation; and 5) evaluating interpretations. The learning activities included Guessing with six words/ phrases, Picture focus, Book talk, Have your say, Sculpture drama, and Drawing a picture. The overall lesson plan content validity mean score was 4.89 and the standard deviation (SD) was 0.16. Cronbach's alpha coefficient was applied to assess reliability (internal consistency) of the lesson plan items, resulting in a reliability value of 0.50 .

Second, a reading test was designed to assess the participants' reading ability before and after implementing the six learning activities. The test consisted of nine open-ended questions reflecting 'Can do statements' from CEFR at $\mathrm{C} 1$ level on the topics of expressing a personal response to creative texts and analysis and criticism of creative texts, as well as corresponding to Bloom's (1956) levels of critical thinking skills. Participants were requested to read the story, The Magic Pot, carefully and to respond to the questions. The questions were approved by three experts in the field of English literature and English language teaching. The Index of Item-Objective Congruence (IOC) was used to indicate content validity. Items with scores lower than 0.5 were revised. Conversely, items with scores higher than or equal to 0.5 were reserved. The overall IOC score of the survey was 0.96 . Reliability of the survey was determined to ensure the responses collected through the instrument were reliable and consistent. The instrument was pilot tested with 25 second-year English major students studying an Introduction to Literature course at a university in the northern part of Thailand. These participants were not in the sample of the main study.

Third, a writing rubric was developed using descriptions from CEFR at $\mathrm{C} 1$ level in the topics of expressing a personal response to creative texts and analysis and criticism of creative texts, as well as corresponding to Bloom's (1956) levels of critical thinking skills. The writing rubric was then verified by the same experts to guide assessment of the students' reading ability in a pre- and post-reading test and their critical thinking skills in the reflective journals. The writing rubric's mean content validity score was 4.66 and the SD was 0.58 .

Fourth, the reflective journals were personal records or writings of the students' opinions towards the stories they engaged with in class.

Fifth, the semi-structured interview questions were designed to explore the students' opinions towards the learning activities using Reader-Response theory. The questions were loosely structured to focus on the interviewees' attitudes toward three main topics: literary texts used, activities used in class, and definition and 
significance of critical thinking skills. Following a review of the questions by the same experts mentioned above, some changes were made to improve their clarity and simplicity. Ethical approval for this study was obtained from the University of Phayao Human Ethics Committee.

\subsection{Procedure}

Fieldwork for this research study took place in 2021 from April to June. During the first stage of the study, the reading test was implemented as a pre-test to assess the participants' reading ability. Next, six lesson plans using Reader-Response theory were implemented in the literature studies classroom over 10 weeks; three hours per week for a total of 30 hours. After reading each text, the students were asked to write a reflective journal on the plot, theme, or a character's actions and behaviours. After finishing all six lessons, a post-test was administered to the participants to assess their reading ability. Semi-structured individual interviews were then conducted with the students at the end of the course to explore their perspectives of the learning experiences based on in-class activities using Reader-Response theory. All interviews were conducted in Thai via online platform, took approximately 20 minutes' duration, and were audio-recorded with the interviewee's permission. Content analysis of the students' interview responses was performed using the three main themes addressed in the interview; namely, literary texts used, activities used in class, and definition and significance of critical thinking skills.

\section{Results}

\subsection{Students' Reading Ability}

The first research question explored the extent to which the use of literature activities based on Reader-Response theory improved reading skills of EFL students according to CEFR at $\mathrm{C} 1$ level. Analysis of the quantitative data was performed via t-tests to provide statistical measurements of any improvement in the participants' reading ability after participating in the Reader-Response theory-based activities to develop reading ability.

Table 2. Comparison of Reading Ability Pre-test and Post-test Scores

\begin{tabular}{lclllll}
\hline Source & $\overline{\mathrm{X}}$ & $\mathrm{SD}$ & $\overline{\mathrm{D}}$ & $\mathrm{S}_{\text {. D. }} \mathrm{D}$ & $\mathrm{t}$ & Sig. (1-tailed) \\
\hline Pre-test & 12.01 & 2.928 & & & & \\
& & & 4.24 & 3.962 & $7.346^{*}$ & 0.000 \\
Post-test & 16.26 & 4.061 & & & & \\
\hline
\end{tabular}

As seen in Table 2, the students' pre- and post-test reading ability scores were compared. The mean score for the post-test (16.26) was significantly higher than the mean score for the pre-test (12.01) at the 0.05 level. This indicates the purposefully designed learning activities helped the participants to improve their reading ability. No outliers were identified in the post- test reading ability scores and the distribution appeared to be approximately normal as supported by right skewness and kurtosis standardised values $(0.398,0.347,-0.769$ and 0.681 , respectively). 


\subsection{Students' Critical Thinking Skills}

Table 3 shows mean and standard deviation scores for student critical thinking skills from reflective writings:

Table 3. Mean and Standard Deviation Scores for Student Critical Thinking Skills from Reflective Writings

\begin{tabular}{|c|c|c|c|}
\hline Student No. & $\overline{\mathrm{X}}$ & S.D. & Band \\
\hline 1 & 9.9 & 0.54 & Average \\
\hline 2 & 11.2 & 4.00 & Average \\
\hline 3 & 16.6 & 2.80 & Average \\
\hline 4 & 10.8 & 3.06 & Average \\
\hline 5 & 10.9 & 5.30 & Average \\
\hline 6 & 16.9 & 4.32 & Average \\
\hline 7 & 14.4 & 3.25 & Average \\
\hline 8 & 13.5 & 4.59 & Average \\
\hline 9 & 10.8 & 4.38 & Average \\
\hline 10 & 13.9 & 3.40 & Average \\
\hline 11 & 18.1 & 8.07 & High \\
\hline 12 & 15.4 & 6.82 & Average \\
\hline 13 & 11 & 3.62 & Average \\
\hline 14 & 16.3 & 7.75 & Average \\
\hline 15 & 15.4 & 5.12 & Average \\
\hline 16 & 18.8 & 5.51 & High \\
\hline 17 & 15.9 & 5.48 & Average \\
\hline 18 & 17.9 & 6.40 & Average \\
\hline 19 & 7.9 & 4.19 & Low \\
\hline 20 & 14.3 & 5.66 & Average \\
\hline 21 & 12.2 & 2.01 & Average \\
\hline 22 & 17 & 3.01 & Average \\
\hline 23 & 19.1 & 1.62 & High \\
\hline 24 & 14.9 & 2.69 & Average \\
\hline 25 & 11.9 & 4.25 & Average \\
\hline 26 & 15.1 & 6.94 & Average \\
\hline 27 & 9.3 & 3.17 & Average \\
\hline 28 & 19 & 4.62 & High \\
\hline 29 & 12 & 2.62 & Average \\
\hline 30 & 13.3 & 4.06 & Average \\
\hline 31 & 13.5 & 6.54 & Average \\
\hline Student No. & $\bar{x}$ & S.D. & Band \\
\hline 32 & 16.1 & 4.75 & Average \\
\hline 33 & 13.7 & 4.37 & Average \\
\hline 34 & 13.7 & 4.58 & Average \\
\hline 35 & 13.4 & 7.35 & Average \\
\hline 36 & 16.2 & 5.64 & Average \\
\hline 37 & 7.8 & 2.34 & Low \\
\hline 38 & 9.5 & 2.53 & Average \\
\hline 39 & 10.9 & 4.40 & Average \\
\hline 40 & 7.7 & 4.35 & Low \\
\hline 41 & 9.5 & 4.34 & Average \\
\hline 42 & 9.7 & 4.34 & Average \\
\hline 43 & 22.6 & 3.43 & High \\
\hline 44 & 11.6 & 5.00 & Average \\
\hline 45 & 15.2 & 3.26 & Average \\
\hline 46 & 17 & 4.16 & Average \\
\hline 47 & 12.1 & 3.96 & Average \\
\hline $\bar{X}$ & 13.7 & 4.36 & Average \\
\hline
\end{tabular}


The data in Table 3 show the highest mean score for the students' reflective writing was 22.6 and the lowest mean score was 7.7. Five students achieved scores in the 18.01 to 27.00 range (High level), 39 students achieved scores in the 9.01 to 18.00 range (Average level), and 3 students achieved scores in the 1.00 to 9.00 range (Low level).

According to the rubric for evaluating critical thinking skills as reflected in the participants' reflective writing, the data revealed that the scores achieved by most participants $(n=39)$ were 9.01 and 18.00 , which are within the average level. As indicated in Table 1, the students could: describe plot, setting, and character in some parts but possibly with some inaccuracies (Knowledge domain); express feelings and emotions towards literary texts, explain why certain parts or aspects of a work interested him/ her but unable to support their explanations with examples and arguments; explain relationships between characters, significance of events, and conflicts but unable to support the explanations with examples and arguments (Comprehension domain); make connections between aspects of the texts and his/ her real-life experience without supporting detail from the story (Application domain); analyse the author's purpose, point of view, theme, trains of thought and feelings, and writing style in some aspects with some supporting detail from the story; compare two works, considering themes, characters and scenes in some aspects with some supporting detail from the story (Analysis domain); and evaluate the extent to which a work meets the conventions of its genre in some aspects with some supporting detail from the story, evaluate the effectiveness of writing techniques in some aspects with some supporting detail from the story, evaluate the character's action and decisions in some aspects without a reasoned argument and sufficient examples from the story (Evaluation domain).

Three student participants achieved a score in the 1.00 to 9.00 range, suggesting they could describe brief details about plot, setting, and character but possibly with some inaccuracies (Knowledge domain); express feelings and emotions towards literary texts, explain why certain parts or aspects of a work interested him/ her but possibly with some unclear or inadequate supporting details; explain relationships between characters, significance events, and conflicts with limited details and examples (Comprehension domain); make limited connections between aspects of the texts and his/ her real-life experience (Application domain); analyse the author's purpose, point of view, theme, trains of thought and feeling, and writing style in some aspects but with inadequate supporting detail from the story; analyse the author's purpose, point of view, theme, traits of thought and feeling, and writing style in some aspects without supporting detail from the story; compare two works considering themes, characters, and scenes in some aspects without supporting detail from the story (Analysis domain); and evaluate the extent to which a work meets the conventions of its genre in some aspects without supporting detail from the story, evaluate the effectiveness of writing techniques in some aspects without supporting detail from the story, and evaluate the character's actions and decisions with limited details and without a reasoned argument and sufficient examples from the story (Evaluation domain).

Five students achieved scores in the 18.01 to 27.00 range reflecting high level critical thinking skills. This indicates that the students could fully describe plot, setting, and character with accurate details (Knowledge domain); express feelings and emotions towards literary texts, explain why certain parts or aspects of a work interested him/ her with full details and support with examples from the story; explain relationship between characters, significance of events, and conflicts with full details and support with examples from the story (Comprehension domain); make connections between aspects of the texts and his/ her real-life experience with supporting details from the story (Application domain); analyse the author's purpose, point of view, theme, traits of thought and feeling, and writing style in all aspects with supporting detail from the story; compare two works considering themes, characters, and scenes in all aspects with supporting detail from the story (Analysis domain); and evaluate the extent to which a work meets the conventions of its genre in all aspects with supporting detail from the story, evaluate the effectiveness of writing techniques in all aspects with supporting detail from the story, evaluate the character's actions and decisions in all aspects with a reasoned argument and sufficient examples from the story (Evaluation domain). 
Table 4. Mean and standard deviation scores for student critical thinking skills related to their reflective writings on six literary texts

\begin{tabular}{lll}
\hline Literary texts & $\overline{\mathrm{X}}$ & $\mathrm{SD}$ \\
\hline Cat in the Rain & 11.94 & 3.90 \\
Little Red Riding Hood & 11.98 & 4.60 \\
The Little Prince & 8.21 & 3.69 \\
Frankenstein & 15.34 & 4.71 \\
The Ruined Maid & 14.84 & 4.64 \\
To the Virgin, to Make Much of Time & 18.51 & 4.26 \\
Total & 13.70 & 4.36 \\
\hline
\end{tabular}

The results presented in Table 4 show the students gained the highest scores for their responses to, To the Virgin, to Make Much of Time, the last literary text studied in the course $(\overline{\mathrm{X}}=18.51 ; \mathrm{SD}=4.26)$. The lowest score ( $\overline{\mathrm{X}}=8.21 ; \mathrm{SD}=3.69$ ) was for The Little Prince, the third text studied in the course. The mean score across all six stories was 13.70 and the SD was 4.36. Notably, as shown in Figure 1, the students showed significant improvement in their critical thinking skills from their study of the first text to their study of the last text.

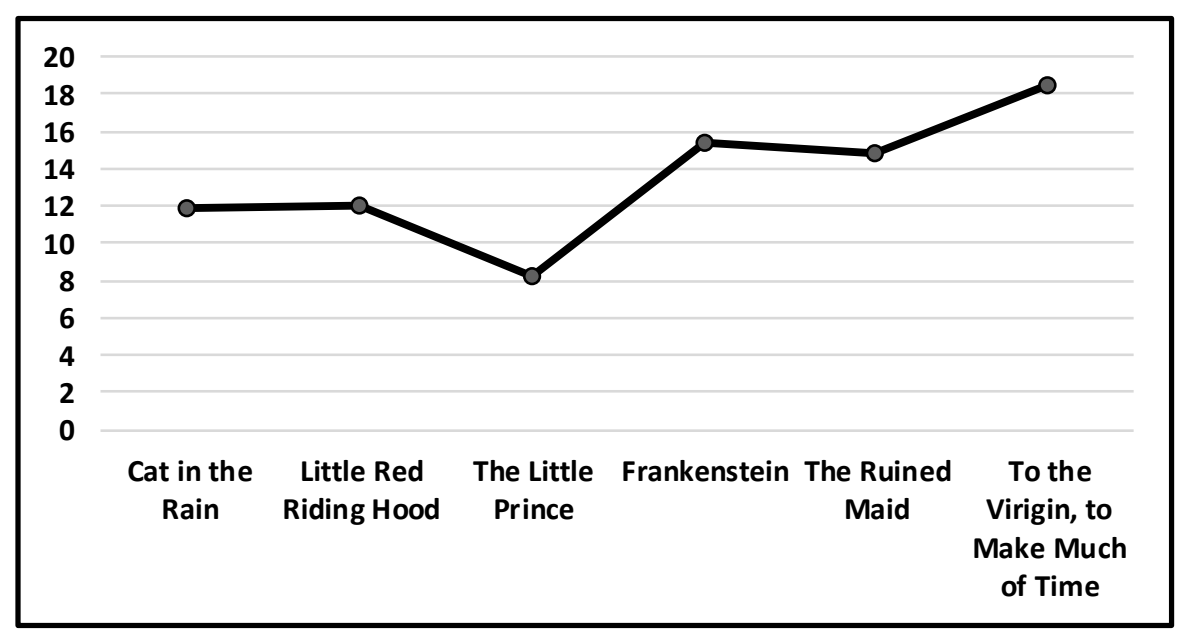

Figure 1. Students' development of critical thinking scores related to their reflective writings on six literary texts

3.3 Students' Attitudes toward the Use of Literature Activities in Developing Reading Skills and Critical Thinking Skills

\subsubsection{Literary Texts Used in Class}

Analysis of the interview data revealed the participants' attitudes towards literary texts used in class in relation to three aspects: the plot was interesting and provoking, the story content was related to the students' real lives, and the texts helped to enhance critical thinking skills as well as intercultural understanding. The participants expressed this sentiment in the following ways:

For me, I think that every story has an interesting plot. Each provides moral lesson to guide us live our life (Interviewee no. 6).

I like Little Red Riding Hood because I think it can relate to my life. In the past, whenever I decide to do something, man always doubts my ability and discourages me (Interviewee no. 1).

I need to use critical thinking skills when I read every story in class in analysing and interpreting the implied meaning such as the author's purpose or the character' decision in doing a particular action in the story (Interviewee no. 7)

I learned about intercultural differences. For example, there is a statement in The Little Prince, "Every man has a star." I think it depends on how people in each culture interpret the meaning of "star" as a symbol. For some, they may think that "star" is a goal in life, while others think that it refers to a lover (Interviewee no. 7). 


\subsubsection{Activities Used in Class}

\subsubsection{Activities in Class to Develop Reading Skills}

Drawing on the interview data analysis results, most participants mentioned two activities that helped to develop their reading skills: Guessing with words/ phrases, and Book Talk. They claimed that the former promoted reading skills in a way that required them to review the story for more details so that they could share their opinions with friends. In addition, they could compare their own story with the story they were about to read in class. Regarding the latter, the participants stated that it stimulated them to reread the story for further interpretation. For example:

I think that creating sentences and story from the words and phrases given by the teacher in 'Guessing with words' activity is the activity that most help developing reading skills (Interviewee no.6).

Book Talk helps me to improve reading skills. I need to review the story in order to gather more information to discuss with my friends (Interviewee no.9).

\subsubsection{Activities in Class to Develop Critical Thinking Skills}

With regard to the learning activities to enhance student critical thinking skills, four activities were mentioned by most participants including Book Talk, Guessing with words/ phrases, Drawing a Picture, and Picture Focus. First, most participants claimed they had learnt a lot from Book Talk. This was because it encouraged them to be open-minded and to widen their perspectives when listening to the opinions of group members. Examples of participant comments indicating this sentiment include:

I learned many things from class discussion. I like when the students share ideas to class because I can listen to what other people thought about the same issues. I could compare their points of view and interpretation as well as evaluate my own interpretation about the story (Interviewee no. 6).

Second, the participants mentioned that the Guessing with words/ phrases activity helped to promote critical thinking because they needed to analyse how the words and phrases given by the teacher related to one another and then create their own story using those words and phrases. For example:

I think that I demonstrate critical thinking skills through Guessing with words and phrases activity most. I need to analyse and examine the relationship or connection of the six words and phrases given by the teacher before using them to create my own predicted story (Interviewee no. 2).

Third, Drawing a Picture was mentioned by most participants as a way to help develop their critical thinking skills by having to interpret the story theme and by encouraging the use of imagination. Interviewee no. 9 stated:

After I finish reading the story, I need to interpret the story theme and analyse how to express it into a picture. In this way, critical thinking skills and imagination is required to complete this task.

Fourth, another activity the participants viewed as potentially enhancing their critical thinking skills was Picture Focus. They reported that they had to decide and evaluate which pictures were related to the story. Interviewee no. 9 expressed this as follows:

For Picture Focus, when the teacher shows us the pictures, we have to decide and evaluate which pictures are related to the story and reflect what happened in those pictures (Interviewee no. 9).

\subsubsection{Definition and Significance of Critical Thinking Skills}

\subsubsection{Definition and Significance of Critical Thinking Skills}

Towards the definition of critical thinking skills, most participants characterised it as the use of reason and justification of one's own actions and decisions. Additionally, most participants agreed that critical thinking is an essential skill for living and working in the $21^{\text {st }}$ century. This thought this particularly in verbal communication when communicating with others because they needed to choose words carefully given their word choices could build or damage their relationship with others. 


\subsubsection{Critical Thinking Skills in Literary Study}

With regard to the participants' opinions towards critical thinking skills in literary study, most claimed that such skills were important when studying literature to analyse characters, themes, and the significant issues embedded in the story

\subsubsection{Self-Evaluation in Critical Thinking Skills}

The participants were aware of the development in their critical thinking skills after participating in the purposefully designed learning activities. Most claimed that their critical thinking skills were at a moderate level based on their lack of in-depth understanding of the characters and plot. Some participants compared themselves with others to suggest they could not think as critically as their friends did.

\section{Discussion}

The data analysis results of this study reveal that the Reader-Response activities implemented in the literature studies class had a significant role in improving student reading ability of CEFR at C1 level as well as critical thinking skills. This was primarily achieved via changes in the reader's role from passive to active. Participating in the various activities based on Reader-Response theory enabled the students to be active and reflective rather than passively absorbing what they read. The students were required to create certain expectations in every phase of reading and draw on their individual backgrounds and experiences to decide on the meaning using their imagination (Iser, 1978). In this respect, they were encouraged to begin their initial impression and search for multiple perspectives and interpretations.

In a nutshell, the findings to emerge in this study show that learning activities drawing on Reader-Response theory in this study improved student reading ability of CEFR at C1 level as well as critical thinking skills. Regarding the CEFR theme of expressing a personal response to creative texts including literature, the "can do statement' describes how learners at $\mathrm{C} 1$ level should be able to:

describe in detail his/ her personal interpretation of a work, outlining his/ her reactions to certain features and explaining their significance, outline his/ her interpretation of a character in a work: their psychological/ emotional state, the motives for their actions and the consequences of these actions, give his/ her personal interpretation of the development of a plot, the characters and the themes in a story, novel, film or play, and give a clear presentation of his/ her reactions to a work, developing his/ her ideas and supporting them with examples and arguments (Council of Europe, 2018: 116).

The research results reflect the students' reading ability of CEFR at $\mathrm{C} 1$ level i five main aspects focusing on their responses to a literary work. In particular, their ability to explain what they like or was interesting about the work, describe characters, relate to their own experiences, relate their feelings and emotions, and interpret the texts. In terms of analysis and criticism of creative texts including literature recommended for learners at higher levels of education who are required to demonstrate higher order thinking skills, the CEFR scales emphasise "comparing different works, giving a reasoned opinion of a work, and critically evaluating features of the work, including the effectiveness of techniques employed" (Council of Europe, 2018: 117).

The findings also revealed the students' reading ability as reflected in the 'can do statement' describing how learners at $\mathrm{C} 1$ level can "critically appraise a wide variety of texts including literary texts of different periods and genres, evaluate the extent to which a work meets the conventions of its genres, describe and comment on ways in which the work engages the audience" (Council of Europe, 2018: 117). Regard the main aim of CEFR and the principle of describing learners' language ability according to what they can do at each level rather than attempting to evaluate what they have not yet achieved (Council of Europe, 2018), the findings from this study has clearly shown that the students could demonstrate their language ability according to the description in the C1 level 'can do statement'. Specifically, there was improvement in literary reading ability as evidenced by the post-test reading ability score (16.26) which was significantly higher than the mean score for the pre-test (12.01) at the 0.05 level.

Furthermore, it is clear from the reflective journal writing results that participating in the literature activities based on Reader-Response theory significantly improved the students' critical thinking skills from their study of the first text to their study of the last text. Most students' scores reflected critical thinking skills at the average level for all five domains including Knowledge, Comprehension, Application, Analysis, and Evaluation. The findings positively indicate the students' potential to develop their critical thinking skills at a higher level and become better critical thinkers in the foreseeable future. 
Lastly, this study focused on the students' attitudes toward the use of literature activities to develop reading skills and critical thinking skills. The interview data revealed that in terms of the literary texts used in class, the students found the plots interesting and provoking, the story content relatable to their real lives, and that the texts helped to enhance their critical thinking skills as well as intercultural understanding. Four activities were mentioned by the students for helping to develop their reading skills and critical thinking skills: Book Talk, Guessing with words/ phrases, Drawing Picture, and Picture Focus. They claimed that Book Talk prompted them to do a review of the story for more details and to try further interpretation in order to share their opinions with friends. It encouraged them to be open-minded and to broaden their perspectives when listening to the opinions of group members. Moreover, they could analyse how the words and phrases provided by the teacher related to one another and then create their own story using those words and phrases in Guessing with words and phrase activity. Furthermore, the students mentioned that Drawing Picture helped to develop their critical thinking skills by interpreting the story theme and encouraging the use of imagination. Finally, in Picture Focus, they were required to decide and evaluate which pictures were related to the story.

In a nutshell, the findings to emerge in this study show that learning activities drawing on Reader-Response theory improved students' reading ability of CEFR at C1 level and critical thinking skills. Focusing on the text, the readers, and the readers' interactions, the design of the learning activities reflected a Reader-Response theory via 1) building schema knowledge, 2) interacting with texts, 3) creating initial response and interpretation, 4) sharing and discussing response and interpretation, and 5) evaluating interpretation. In this respect, the students felt encouraged during their interactions with the literary texts to express their feelings and thoughts towards the characters and the texts through the designed activities. That is, by means of in-class activities, the students were provided with opportunities to interact with texts, express their feelings and ideas, listen to their friends' opinions, and share and critically reflect on their points of view and interpretations. In this regard, not only does reading literature enhance students' reading ability, but it also improves critical thinking skills through the Reader-Response based learning activities.

\section{Conclusion}

The research results shed light on the potential to develop reading ability according to CEFR at $\mathrm{C} 1$ level as well as critical thinking skills by implementing Reader-Response based activities with EFL students entering into the global workforce of the $21^{\text {st }}$ century. The activities were designed to motivate students to actively engage in the reading process and to reflect on their own feelings without merely absorbing the information written in that text. By focusing on the role of the readers and their experiences in the reading process, readers are invited to begin their initial impression and search for multiple perspectives and interpretations. Moreover, they can discuss the significant issues embedded in the stories to generate new ideas. The six activities included in this study were Guessing with six words/ phrases, Picture focus, Book talk, Have your say, Sculpture drama and Drawing Picture. It should be noted however that the limitation of this research lies in the small sample. This may limit the generalisability of the findings and make comparison with other studies difficult. Further studies should attempt to increase the sample size and to incorporate more students from other fields of study. Moreover, a comparative study investigating reading ability and critical thinking skills between students with different level of proficiency or other CEFR levels is also recommended.

\section{Acknowledgements}

The research was supported by University of Phayao (Unit of Excellence).

\section{References}

Bloom, B. S. et al. (1956). Taxonomy of Educational Goals: Handbook1: Cognitive Domain. New York: David McKay.

Cambridge English. (2016). International language standards. Retrieved from https://www.cambridgeenglish.org/exams/cefr/

Carrison, C., \& Ernst-Slavit, G. (2005). From silence to a whisper to active participation: Using literature circles with ELL students. Reading Horizon, 46(2), 93-113.

Collie, J., \& Slater, S. (2001). Literature in the language classroom: A resource book of ideas and activities. Ambridge: CUP.

Council of Europe. (2001). Common European framework of reference for languages: Learning, teaching, assessment. Retrieved from https://www.coe.int/lang-cefr 
Council of Europe. (2018). Common European framework of reference for languages: Learning, teaching, assessment. Companion volume with new descriptors. Retrieved from https://www.coe.int/lang-cefr

Dewey, J. (1909). How we think. D.C. Health and CO. https://doi.org/10.1037/10903-000

Ennis, R. H. (1987). A Taxonomy of Critical Thinking Disposition and Abilities. In Sternberg, R. J., \& Baron, J. B. (Eds.), Teaching Thinking Skills: Theory and Practice (pp. 9-22). New York: W. H. Freeman and Company.

Fisher, R. (2003). Teaching Thinking. London: Continuum.

Foley, J. A. (2019). Adapting CEFR for English language education in ASEAN, Japan and China. The New English Teacher, 13(2), 101-117.

Fulcher, G. (2004). Deluded by artifices? The common European framework and harmonization. Language Assessment Quarterly, 1(4), 253-266. https://doi.org/10.1207/s15434311laq0104_4

Glaser, E. (1941). An experiment in the development of critical thinking. New York: Teacher's College, Columbia University.

Hosseini, M., \& Safari, M. (2018). Exploring the potential of explicit/implicit teaching through plays for EFL learners' pragmatic development. The Journal of Asia TEFL, 15(4), 1065-1082. https://doi.org/10.18823/asiatefl.2018.15.4.12.1065

Iser, W. (1978). The Act of Reading: A Theory of Aesthetic Response. Baltimore: Johns Hopkins University Press.

Jauss, H. (1981). Toward an aesthetic of reception. Minneapolis: University of Minnesota Press.

Jiménez-Muñoz, J. (2014). Measuring the impact of CLIL on language skills: a CEFR based approach for Higher Education. Language Value, 6(1), 28-50. https://doi.org/10.6035/LanguageV.2014.6.4

Jones, C., \& Carter, R. (2012). Literature and language awareness: Using literature to achieve CEFR outcomes. Journal of Second Language Teaching and Research, 1(1), 69-82. https://doi.org/10.5420/jsltr.01.01.3320

Kanchai, T. (2019). Thai EFL university lecturers' viewpoints towards impacts of the CEFR on their English language curricula and teaching practice. NIDA Journal of Language and Communication, 24(35), 23-47.

Kaowiwattanakul, S. (2005). Factors contributing to the development of critical thinking skills in the undergraduate literature classroom. (Unpublished master's thesis). University of Southampton, Southampton, United Kingdom.

Kaowiwattanakul, S. (2009). Critical Thinking in the L2 Literature Classroom in Thai Universities: Conceptions and Pedagogical Practices. Mauritius: VDM Publishing House.

Kaplan, C. (2005). Critical thinking in literary studies. In Kaowiwattanakul, S. (Ed.), Factors contributing to the development of critical thinking skills in the undergraduate literature classroom (Unpublished master's thesis). University of Southampton, Southampton, United Kingdom.

Langer, J. A. (1992). Critical Thinking and English Language Arts Instruction. Albany, New York: National Research Center on Literature Teaching and Learning, State University of New York.

McGavin, J. (2005). Critical thinking in literary studies. In Kaowiwattanakul, S. (Ed.), Factors contributing to the development of critical thinking skills in the undergraduate literature classroom. (Unpublished master's thesis). University of Southampton, Southampton, United Kingdom.

Ministry of Education. (2014). Monitoring and assessing English language learning and teaching policy report for serving Thailand 4.0. Bangkok: Triple Group.

Phaisannan, T., Charttrakul, K., \& Damnet, A. (2019). The CEFR-TBL in fostering pre-service teachers' English speaking ability using the peer interview task. Advances in Language and Literary Studies, 10(5), 10-19. https://doi.org/10.7575/aiac.alls.v.10n.5p.10

Reiter, A. (2005). Critical thinking in literary studies. In Kaowiwattanakul, S. (Ed.), Factors contributing to the development of critical thinking skills in the undergraduate literature classroom (Unpublished master's thesis). University of Southampton, Southampton, United Kingdom.

Rew, S., \& Moon, Y. (2013). The effects of using English drama on the learning of target expressions for primary school students. The Journal of Asia TEFL, 10(4), 215-239.

Rosenblatt, L. (1938). Literature as Exploration. New York: Appleton-Century. 
Taylor, L. (2004). Issues of test comparability. Research Notes, 15, 2-5.

Waluyo, B. (2019). Thai first-year university students' English proficiency on CEFR levels: A case study of Walailak University, Thailand. The New English Teacher, 13(2), 51-71.

Yilmaz, C. (2012). Introducing literature to an EFL classroom: Teacher's instructional methods and students' attitudes toward the study of literature. English Language Teaching, 5(1), 86-99. https://doi.org/10.5539/elt.v5n1p86

Zou, S., \& Zhang, W. (2017). Exploring the adaptability of the CEFR in the construction of a writing ability scale for test for English majors. Language Testing in Asia, 7(18), 1-16. https://doi.org/10.1186/s40468-017-0050-3

\section{Copyrights}

Copyright for this article is retained by the author(s), with first publication rights granted to the journal.

This is an open-access article distributed under the terms and conditions of the Creative Commons Attribution license (http://creativecommons.org/licenses/by/4.0/). 